\title{
Decolonization, Language, and Identity: \\ The Francophone Islands of the Pacific
}

\section{Léopold Mu Si Yan and Bruno Saura}

The Contemporary Pacific seeks to engage with the region of Oceania as a whole. Yet significant distances between anglophone and francophone scholarship remain despite periodic efforts to bridge the various geographical, historical, linguistic, and scholarly divides. This special issue focuses on analyses of indigenous identities (Kanak and Mā'ohi) in the francophone islands of the Pacific. With contributions from contemporary scholars of New Caledonia and French Polynesia, it recognizes and brings their research and the cultural, social, and political struggles of their interlocutors to better visibility for a broad, largely anglophone audience in Pacific studies.

This issue also highlights how francophone scholars who work in this region-some of them rooted in their research communities by birth or ancestry-have their own frame of reference and a disciplinary and interdisciplinary "intertextuality" vis-à-vis the region as a whole that overlaps with but may be significantly distinct from that of scholarly conversations elsewhere in Oceania. Even though the contributors are very familiar with English-language scholarly literatures of the region, their work is intriguingly positioned in The Contemporary Pacific because it is mainly based on indigenous and French-language sources that are not always and perhaps not often available to anglophone regional scholarship. This special issue offers non-readers of French an opportunity to gain greater depth and breadth with regard to contemporary research trends in these territories and beyond.

Admittedly, it may be tricky, if not impractical, to single out (beyond the variety of disciplinary approaches and over several generations as well) a common denominator in research produced by French scholars that marks it as distinctly different from the work of Anglophones. This may be just as difficult as trying to classify the work of scholars based on

The Contemporary Pacific, Volume 27, Number 2, 325-335

(C) 2015 by University of Hawai'i Press 
age, gender, or other factors. On the other hand, in highlighting methodologies or topics specific to Francophones, we are thinking about emphasizing specific cultural and scientific backgrounds and traditions that may inform and mold the content and style of research. Basically, Francophones and Anglophones conduct research studies on history, linguistics, arts, religion, and so on, along the same lines. Still, a singular dividing line has been identified quite recently by Véronique Fillol and Pierre-Yves Le Meur (20I4, 22): They suggest it may be possible to differentiate between French-speaking researchers of varied ethnic origins who are permanent residents of New Caledonia or French Polynesia, on the one hand, and others doing research on Oceania, including both non-Francophones and Francophones born and based outside of the French Pacific, on the other.

The latter, driven by ethics and "in the name of a universalist legitimization of science and truth" (Fillol and Le Meur 2014, 22), are supposedly prone to openly speak out against cases of inequality or colonial domination in the French territories of the Pacific. In contrast (and noting that self-awareness does not enter into it), permanent residents of these French territories are presumably more inclined to consider the consequences of their work on the society in which they live as well as their social standing. As a result of this "consequence-minded posture," they incur "the risk of self-censorship in scientific investigation" (Fillol and Le Meur 20I4, 22). But then other risks may arise, such as an exceedingly narrow scope (due to missing or weak theoretical and comparative outlooks) or a lack of interest in doing "basic" or fundamental research, much to the benefit of "applied" research in the service of local public policies.

In the same vein, one cannot evade the question of the varying political commitments of researchers born or residing permanently in the Frenchspeaking Pacific Islands. This is primarily an issue for scholars of public law, political science, and contemporary history, whose work is sometimes oriented toward a vision of the past but also toward the present and the future of those territories in terms of policy or contemporary decisionmaking processes. The sympathies of some of them are with independence partisans, as is the case today with historian Jean-Marc Regnault in Tahiti. Others tend to promote the sustained links between Oceania and France. So it was with the engaged historian and anthropologist Paul de Deckker for decades, starting from the I980s. Before passing away in 2009, he founded the Maison de la Mélanésie, led today by another historian, Frédéric Angleviel, a native of New Caledonia.

More specifically, one can raise the issue of whether francophone 
researchers-partly influenced as they are by a French republican culture that views society as an aggregate of equal individuals, dismissing any ethnic community—are likely to describe Kanak society or Mā'ohi society in terms of ethnicity and indigenousness. Are they less involved in these topics compared with Anglophones? Some answers have been given to this query in a book titled Autochtonies: Vues de France et du Québec, edited by Natacha Gagné, Thibault Martin, and Marie Salaün (2009). The fact is that scholars trained in French universities are less sensitive to communitarian or ethnic issues than their anglophone counterparts. In France there exist very few institutes-let alone academic degrees-in the fields of women's studies, gender studies, ethnic studies, or, most pertinent to the discussion at hand, Pacific studies. Notwithstanding, ethnologists and anthropologists have a natural vocation to undertake research on ethnic issues. Accordingly, French ethnologists and anthropologists do not shy away from identity, ethnic, or autochthony questions in the Pacific or elsewhere. By the same token, approaches to genre distinctions inspired by American academia are fairly common among French anthropologists: see, for instance, Serge Tcherkézoff and Françoise Douaire-Marsaudon's The Changing South Pacific: Identities and Transformations (2005). For that matter, French- and English-speaking researchers often collaborate on those subjects, as evidenced by the book Oceanic Encounters: Exchange, Desire, Violence, edited by Margaret Jolly, Serge Tcherkézoff, and Darrell Tryon (2009).

In fact, it is in disciplines other than anthropology that some researchers trained in the French republican tradition may find it difficult to leave some room for the study of ethnic or autochthonous phenomena. But since Paul de Deckker and Jean-Yves Faberon published their seminal work, Custom and the Law (200I), even jurists have addressed the issue of how to reconcile the values of the French Republic with the cultural particularities of New Caledonia, Wallis and Futuna, and French Polynesia (see Leca 20I4). So francophone scholars in the region have increasingly imposed no taboo against ethnic issues.

Concretely, this issue of The Contemporary Pacific includes three articles and a dialogue piece dealing with contemporary social and cultural issues in French Polynesia and New Caledonia as navigated and negotiated both collectively and in individual experience. While none of the essays speak directly to the third French territory in the Pacific, Wallis and Futuna (two islands with about fourteen thousand inhabitants), they shed some light on comparative possibilities for future work in this part 
of the French-speaking Pacific as well. In addition, a Resources section provides information about bibliographic and research materials in the two territories.

The art featured in this issue of the journal illustrates new currents in contemporary work by Oceanian artists from French Polynesia and New Caledonia. Contemporary artworks challenging long-enduring representational and stylistic conventions have only appeared comparatively recently, perhaps only in the last decade, in the French Pacific. Notably, for much of the twentieth and still in the twenty-first century, much art in this region has been and is being produced by nonlocal artists keen to make experiments in an Island environment with the changing media and codes of modern art. Conversely, until recently, many local artists rooted in home islands have seemed reluctant to upset traditional artistic forms and styles, often avoiding provocative or bold attitudes and complying instead with the aesthetic canons of the pre-European period. Clearly, the role and practice of art in the French Pacific by local artists has changed. As we see in this issue with the marvelous statuary of Olson Teraiamano and Manaarii Tetauupu, the nearly hallucinatory painting of Denise Tiavouane and Paula Boi Gony, the inspiring mixed-media work of Micheline Néporon, and the calmly disturbing photography of TAHE and MarieHélène Villierme, contemporary Pacific Islander artists in the region are in powerful conversation with modernist twists, challenging viewers to engage with fresh meanings for regional arts in changing contexts. Indeed, the illustrations featured here suggest that local artists feel the time is ripe for irreverence, transgression, and experimentation while maintaining potent connections to the place of nature in island life, to the voices and traditions of ancestors, and to pressing social contexts.

Regarding the four research essays of this special issue, their authors are part of the new generation of researchers investigating the French-speaking Pacific. Natacha Gagné, a French Canadian scholar, is well known for her studies on indigenous struggles in the world, most especially with regard to Māori in New Zealand (20I2a, 20I2b, 20I3). The three other authors-Titaua Porcher-Wiart, Bruno Saura, and Jacques Vernaudonare affiliated with the University of French Polynesia (UPF). Porcher-Wiart joined UPF after teaching French language and literature at the University of Hawai'i at Mānoa (UHM) for the 2OII-I 2 academic year as part of a UHM initiative to engage with French-speaking Oceania. Vernaudon, a linguist by training, taught at the University of New Caledonia (UNC) for nine years. He is a specialist in the teaching of native languages in primary 
schools in New Caledonia as well as in French Polynesia, where he, like Porcher-Wiart, was born. English readers may be familiar with the writings of Saura that address the topics of Polynesian traditions (2002) and the various expressions of Tahitian nationalism (I998, 200I, 20II).

It is worth saying a few words about UPF and UNC, the two francophone universities of the region, as the bulk of research in the fields of literature and human science and more specifically on French Pacific territories is conducted there. UPF and UNC are the products of the split of the former Université Française du Pacifique in 1999. That institution was set up in I987 to provide local populations with easier access to higher education, to give impetus to French research in the region, and, to put it bluntly, to offer an image of France different from that of a nuclear power.

Until 1987, French research on the Pacific was designed and directed in Paris. Initially, this was done within such institutions as the Musée de l'Homme, the Institut National des Langues et Civilisations Orientales, and the Muséum d'Histoire Naturelle. Things changed in the early I960s with the opening in both Nouméa and Papeete of two agencies of orstom (Office de la Recherche Scientifique et Technique Outre-Mer). It was in those facilities that significant research was done for thirty years in human and social science (archaeology, sociology, anthropology, linguistics), alongside natural science programs. Researchers came for the most part from metropolitan France but research was done locally, in the Pacific, and over extended periods of time. The newly created Université Française du Pacifique took over in actual practice from the two agencies of ORSTOM (which evolved in I984 into IRD, Institut de Recherche Scientifique et Technique pour le Développement) with respect to research in human science. This was done through the gradual involvement of academics hailing from the two territories who, in turn, helped train a new generation of Oceania-born scholars up to and including the doctoral level. In addition, the decolonization process starting in New Caledonia in the late I980s was complemented by a blueprint for undertaking multiple research projects to preserve and promote indigenous languages and cultures, to understand and help solve land issues, and to foster endogenous development, while ensuring the full training of Oceania-born researchers. The Paris-based École des Hautes Études en Sciences Sociales (EHESS) ran a program called Études des Sociétés Kanak (ESK) with special funding from the Overseas Departments and Territories Ministry and the Culture Ministry (Mission du Patrimoine Ethnologique), thus contributing to the organizing of conferences, the supervision of doctoral dissertations, and 
the publication of studies. Among the latter, En pays kanak, a book edited by Alban Bensa and Isabelle Leblic (2000), is an outstanding example of a work coming out of French regional scholarship that would interest a broad Pacific audience were it not for the legacies of linguistic divides.

Thus, in the early twenty-first century, there is no dearth of francophone research on New Caledonia and French Polynesia. One may actually say there is an overdue and welcome scholarly blossoming, as these articles and books are little known to anglophone specialists of the region. Admittedly, French and Oceanians who are natives of these two territories hold no monopoly on research there since a number of Australians, New Zealanders, and Americans are still engaged in numerous short- and longterm research projects in the region. They are carrying on a great tradition started in the I920s in French Polynesia by American researchers from the Bishop Museum of Honolulu, with Kenneth Emory as the foremost figure. Their work touched on ancient Polynesian traditions, in the realms of languages, oral lore, pre-Christian traditions, religious sites and systems of practice, and material culture. In the I950s and I960s, a second wave of American researchers led by ethnologist Douglas Oliver tackled in French Polynesia fresh topics more oriented toward social change. Ben Finney, to whom the University of French Polynesia awarded the title of doctor honoris causa in 2007 , figured among them.

Gone now are the days of big research teams. But dedicated scholars affiliated with different universities of the region are keeping alive the flame of research into the cultures and populations of the francophone Pacific. This is exemplified by the recent studies of Anne Salmond on Tahiti in the eighteenth century (20II), Raylene Ramsay on francophone literature in Oceania (20I I, 20I4), Miriam Kahn on tourism and militarism in the post-nuclear French Pacific (20II), Jennifer Newell on ecological exchange from the era of early contacts to the present (2010), and David Chappell on the political history of New Caledonia (2013), among many others.

While French presence in these islands has spawned for two generations now the development of research and education benefiting Oceanians first and foremost, the other side of the coin is that French acculturation increasingly disrupts traditional lifestyles. For this reason we chose as the common theme of the main articles the difficulty of maintaining an indigenous identity within the French colonial system. "Being French" (or being part of France) is a political reality in these territories, although local people often associate it with painful memories (see Saura's article, 
"Remembrance of the Colonial Past in the French Islands of the Pacific: Speeches, Representations, and Commemorations"). But if native people of New Caledonia and French Polynesia are preoccupied by identity questions, Gagné's article- "Brave New Words: The Complexities and Possibilities of an 'Indigenous' Identity in French Polynesia and New Caledonia"-explains the reasons for their relative distance from the general framework for the indigenous peoples' struggles as they relate to the world indigenous movement and United Nations indigenous rights instruments.

In all the French territories, the system of education is the key to the process of cultural assimilation. This is currently being challenged by bold initiatives that have established the teaching of indigenous languages in primary and secondary schools, as shown in Vernaudon's dialogue piece, "Linguistic Ideologies: Teaching Oceanic Languages in French Polynesia and New Caledonia." Although being a dependency of France may be in conflict with Mā'ohi and Kanak identities, it is nevertheless a starting point and a framework for developing educational policies and for the emergence of new forms of literary expression, as shown in Porcher-Wiart's article, "Imagining the Body in Pacific Francophone Literature."

A general survey in English of culture and identity issues in New Caledonia and French Polynesia may be lacking-one that would match the fine volume Inside Out: Literature, Cultural Politics, and Identity in the New Pacific, edited by Vilsoni Hereniko and Rob Wilson and published in I999. However, a step was taken in that direction with a special issue of Mànoa: A Pacific Journal of International Writing, titled Vārua Tupu: New Writing from French Polynesia, edited by Frank Stewart, Kareva Mateata Allain, and Alexander Mawyer (2006).

Accordingly, we hope that this special issue of The Contemporary Pacific will contribute in its turn, however modestly, to awaken the interest of non-francophone readers and provide a reading guide to these territories. These plainly share cultural features with other islands and archipelagos in the region although they went separate ways from those that experienced anglophone colonization, due to differences in exposure and the twists and turns of colonial history. Precisely to the point, the Resources section, produced by the chief librarians of the University of New Caledonia and the University of French Polynesia, provides a very useful overview of bibliographic and research materials about these two territories. Beyond the collections in university libraries, the authors also 
discuss other research collections in their respective countries, such as the Musée de Tahiti et des Iles and the Service du Patrimoine Archivistique et Audiovisuel in French Polynesia and the Tjibaou Cultural Center and the South Pacific Commission in New Caledonia. They also address the challenges and potential for increasing communication and collaboration between their home institutions and other similar institutions in the Pacific and Europe, with an eye to developing connections between anglophone and francophone research centers.

Although we do not deal in depth with all the French research institutions, the Resources section of this issue examines research institutions involved in producing and archiving work by scholars based in, or with strong connections to, the francophone Pacific Islands. The well-known CREDO (Centre de Recherche et de Documentation sur l'Océanie), created in 1995 in Marseilles by Pierre Lemonnier, Serge Tcherkézoff, and Maurice Godelier, is one example. It is today in Europe the main pluri-disciplinary center for research and documentation specialized in Pacific studies. With a general orientation in anthropology, archaeology and history, CREDO is also a member of LABEX CORAIL (Laboratory of Excellence for Coral Reefs Facing Global Change) and Ecopas (European Consortium for Pacific Studies, working on climate change in the Pacific). It also hosts the e-Toile Pacifique network of francophone researchers in human and social sciences about the Pacific Islands region (www.e-toilepacifique.fr), a website of the greatest interest.

Even with such excellent centers of Pacific research consistently generating stimulating and ground-breaking work, including fresh epistemological perspectives in discipline-specific theory as well as important empirical studies, it almost goes without saying that scholars conducting research in the region remain widely dispersed. However, the situation is hardly static, and new initiatives are emerging that will further enhance and localize the place of research in the region. A notable example in 20I4: UPF President Eric Conte began coordination and work toward the creation of a Maison des Sciences de l'Homme (Institute for Human Science) to be based at the University of French Polynesia. If successfully created, this institute's role will consist in hosting the existing research teams at the UPF and facilitating connections among researchers affiliated with French overseas and metropolitan institutions-the Centre National de la Recherche Scientifique (CNRS), École des Hautes Études en Sciences Sociales (EHESs), École Pratique des Hautes Études (EPHE)—and with institutions across the region, including the University of Hawai'i at Mānoa, for joint projects, publica- 
tions, conferences, and workshops, among other outcomes. We anticipate exciting years ahead for scholarly and creative work across the region.

In their own way, contemporary researchers in the French Pacific are working on problematics regarding the cultural grounding of Oceanian societies and their encounters with the Western world and on more contemporary subjects related to identity, environment, and globalization issues (see Le Monde Pacifique dans la mondialisation, a special issue of the journal Hermès, edited by Dominique Barbe and Renaud Meltz [20I3]). The pieces assembled in this special issue convey the vitality and vibrancy of cultural and scholarly life in the contemporary French-speaking islands of the Pacific.

To all our readers, we wish you an enjoyable and enriching experience. Bonne lecture!

We WOUlD LiKe TO ACKNOWLEDGe our deep gratitude to Terence Wesley-Smith. But for his friendly support and patience, and his vision of a reconnection between anglophone and francophone researchers in the Pacific, this project would never have come to fruition. We are deeply thankful to Alex Mawyer, whose scholarly attention to details, energy, generosity, and untiring review of the form and substance of this special issue's articles have been mightily appreciated. Our warmest thanks also go to Jan Rensel and Katherine Higgins as models of professional care, persistence, and enthusiasm.

\section{References}

Barbe, Dominique, and Renaud Meltz, editors

2013 Le Monde Pacifique dans la mondialisation. Special issue of Hermès 65.

Bensa, Alban, and Isabelle Leblic, editors

2000 En pays kanak: Ethnologie, linguistique, archéologie, histoire de la Nouvelle-Calédonie. Paris: Éditions de la Maison des Sciences de l'Homme.

Chappell, David

2013 The Kanak Awakening: The Rise of Nationalism in New Caledonia. Pacific Islands Monograph Series 27. Honolulu: Center for Pacific Islands Studies and University of Hawaici Press.

de Deckker, Paul, and Jean-Yves Faberon, editors

$200 \mathrm{I}$ Custom and the Law. Canberra: Asia Pacific Press, The Australian National University. Previously published as Coutume autochtone et évolution du droit dans la Pacifique Sud. Paris: L'Harmattan, 1995. 
Fillol, Véronique, and Pierre-Yves Le Meur

20I4 Enquête de terrain et décolonisation dans le Pacifique Sud: Science, politique, éthique. In Terrains océaniens: Enjeux et méthodes, edited by Véronique Fillol and Pierre-Yves Le Meur, 9-25. Paris: L'Harmattan.

Gagné, Natacha

20I 2a The Challenge of Indigenous People: Spectacle or Politics? The Australian Journal of Anthropology 23 (2): 263-265.

20I 2b Indigenous Peoples, a Category in Development. In Introduction to International Development Studies: Approaches, Actors, and Issues, edited by Paul Haslam, Jessica Schafer, and Pierre Beaudet, 454-472. 2nd edition. Oxford: Oxford University Press.

2013 Being Māori in the City: Indigenous Everyday Life in Auckland. Toronto: University of Toronto Press.

Gagné, Natacha, Thibault Martin, and Marie Salaün

2009 Autochtonies: Vues de France et du Québec. Quebec: Presses Universitaires Laval.

Hereniko, Vilsoni, and Rob Wilson, editors

I999 Inside Out: Literature, Cultural Politics, and Identity in the New Pacific. Lanham, MD: Rowman \& Littlefield.

Jolly, Margaret, Serge Tcherkézoff, and Darrel Tryon, editors

2009 Oceanic Encounters: Exchange, Desire, Violence. Canberra: ANU Press.

Kahn, Miriam

20I I Tahiti Beyond the Postcard: Power, Place, and Everyday Life. Seattle: University of Washington Press.

Leca, Antoine

20I4 Introduction au droit civil coutumier kanak. Aix-en-Provence: Presses Universitaires d'Aix-Marseille.

Newell, Jennifer

2010 Trading Nature: Tahitians, Europeans, and Ecological Exchange. Honolulu: University of Hawai'i Press.

Ramsay, Raylene

20I I Nights of Storytelling: A Cultural History of Kanaky-New Caledonia. Honolulu: University of Hawai'i Press.

20I4 The Literatures of the French Pacific: Reconfiguring Hybridity.

Salmond, Anne Liverpool: Liverpool University Press.

20I I Aphrodite's Island: The European Discovery of Tahiti. Los Angeles: University of California Press.

Saura, Bruno

I998 The Emergence of an Ethnic Millenarian Thinking and the Development of Nationalism in Tahiti. Pacific Studies 2I (4): 33-66. 
200I The Prophetic and Messianic Dimension of Pouvanaa Oopa (I895I977), Father of Tahitian Nationalism. Canadian Review of Studies in Nationalism 28 (I-2): 45-55.

2002 Continuity of Bodies: The Infant's Placenta and the Island's Navel in Eastern Polynesia. The Journal of the Polynesian Society I I I (2): I 27-I 45 .

20I I L'Identité par les racines, or, Saying "Indigenous" in Tahiti: The Term Mā'ohi. Shima: The International Journal of Research into Island Cultures 5 (2): I-I8.

Stewart, Frank, Kareva Mateata Allain, and Alexander Dale Mawyer, editors

2006 Vàrua Tupu: New Writing from French Polynesia. Mānoa, A Pacific Journal of International Writing I7:2.

Tcherkézoff, Serge, and Françoise Douaire-Marsaudon, editors

2005 The Changing South Pacific: Identities and Transformations. Canberra: Pandanus Books.

\section{Abstract}

This article is both an introduction to this special issue of The Contemporary Pacific and a more general reflection about francophone research in the Pacific Islands and about their cultures and populations. The common topic of the essays selected here is the difficulty of maintaining an indigenous identity within the French colonial system in the French or francophone islands of the Pacific (New Caledonia, French Polynesia, and Wallis and Futuna). Four contributions from contemporary scholars of New Caledonia and French Polynesia bring their research on the cultural, social, and political struggles of their interlocutors to better visibility for a broad, largely anglophone audience in Pacific studies. The Resources section, produced by the chief librarians of the University of New Caledonia and the University of French Polynesia, provides a very useful overview of bibliographic and research materials about these two territories. Putting things in broader perspective, this introduction discusses what may be a common denominator in research work produced by francophone scholars that makes it distinctly different from the work of Anglophones. As well, it raises the epistemological issue of the political commitment of researchers born in the francophone Pacific Islands or living there on a permanent basis.

KEYWORDs: French research, francophone Pacific, New Caledonia, French Polynesia 